\title{
O postsekulárním myšlení
}

\author{
Ivo Pospíšil (Brno)
}

Ve dnech 16.-17. 10. 2017 se ve Varšavě péčí Ústavu západoslovanských a jihoslovanských studií a Ústavu slavistiky Polské akademie věd konala mezinárodní konference The Experience of Faith in Slavic Cultures and Literatures in the Context of Postsecular Thought. Jazykem jednání byla téměř bez výjimky angličtina. Konference se zúčastnili vědci z řady především slovanských zemí, filologové, ale také filmologové, folkloristé, sociologové, politologové aj. Konferenci uvedl děkan fakulty polonistiky Varšavské univerzity prof. dr hab. Zbigniew Greń, ředitel Ústavu západoslovanských a jihoslovanských studií Dr. hab. Patrycjusz Pająk a organizátorka konference Dr. hab. Danuta Sosnowska. Jednání probíhalo jako série panelů, modulů, speciálních přednášek a diskusí.

Problém postsekularity je dnes velmi módní. Je však nezbytné neignorovat vztah mezi metodologií a terminologií. Termíny jako postsecularity (postsekularita), postsecular (postsekulární) na straně jedné a postsecularism (postsekularimus), postsecularist (postsekularistický) jako záměrný vědecký termín proniknutý subjektivním viděním objektu na straně druhé; totéž se týká prefixu "post", jenž vždy nesl podtext nebo spodní proud jistého návratu, ale obohaceného předcházejícími vývojovými stadii, jimiž jsme prošli. Náboženství může svou plnou reálnou roli hrát jen $\mathrm{v}$ teokracii; proto jde mimo teokracii jen o tendenci, jež je viditelná všude v současném světě, i když v každém náboženství v jiném objemu a rozsahu. Když je sféra náboženství v sekulární společnosti vymezena a omezena materialistickým a racionalistickým konceptem, náboženství nemůže plnit svou holistickou úlohu. Náboženství však bude stále žít, bude věčné, pokud budou žít ontické, existenciální aspekty lidského života jako dominanty. Postsekulární stadium společenského vývoje je tedy realizací jednoho z Hegelových zákonů dialektiky - zákona negace negace.
První přednášku pronesl dr Srđan Sremac na téma Religious and Sexual Nationalism Theo-Politics of Blasphemy in Central and Eastern Europe.

V panelu, který se zabýval zvláštní podobou náboženského zážitku, participovali Roman Kečka, Kamila Klingorová, Srđan Sremac, Yuri Stoyanov, Agata Bielik-Robson, Nonka Bogomilova a Anna Krasteva.

V modulu 1 (Religion Beyond Orthodoxy) prezentovaly své názory Paula Kiczek, Magdalena Maszkiewicz a Nemanja Radulović za předsednictví Danuty Sosnowské. Paula Kiczek (Varšava) přednesla svo̊j referát na téma Faith Beyond Doctrines - Faith in the Dialogue: Reflection on Philosophical Anthropology of Milan Machovec. Magdalena Maszkiewicz (Krakov) pojednala o neortodoxním zážitku víry (The Nonorthodox Experience of Faith in Ivan V. Lalićs and Miodrag Pavlovićs Poetry - a Comparative Research). Nemanja Radulović (Bělehrad) pojednala o recepci Velesovy knihy a zklamaném světě (Reception of the Book of Veles and Disenchanted World).

$\mathrm{V}$ rámci modulu 2 (Religious Experience in Gender Perspective) vystoupily Kamila Klingorová, Olga Słowik a Dominika Gapska. Kamila Klingorová (Praha) promluvila na téma Women's Everyday Experience with Religion and Spirituality in Post-Secular Czechia. S referátem A Geographical Approach vystoupili Kamila Klingorová, Tomáš Havlíček a Zdeněk Vojtíšek. Olga Słowik (Praha) demonstrovala některé, především ženské problémy v referátu Saint Fasting Women? Anorexia Mirabilis and Its Traces in Contemporary Czech Literature. Dominika Gapska (Poznaň) pojednala o ženské spiritualitě v Srbsku (Women Spirituality in Post-Secular Serbia. Research Sample).

V modulu 3 (Belief or Mockery - a Real Alternative) se zúčastnily Tsvetelina Dimitrova, Alla Boiko a Elżbieta Benkowska. Tsvetelina 
Dimitrova (Sofia) mluvila o svatých místech ( $S a$ cred Places and National Identity. By Example of Chepino, Velingrad, Southwestern Bulgaria). Alla Boiko (Kyjev) přednášela o komice v chápání náboženství a církve v 21. století (The Palette of Comic in Understanding Religion and Church in the 21st Century), Elżbieta Benkowska (Gdańsk) zkoumala náboženské motivy v popěvcích polských a srbských fotbalových fanoušků (My wierzymy tylko w BKS... Religious Motifs In The Chants of Polish and Serbian Football Fans). V panelu Secularisation, Desecularisation, Postsecularism vystoupili Karina Jarzyńska, Michał Warchala, Stanisław Obirek a Nonka Bogomilova.

V modulu 4 (Religion and Politics) participovali Ivo Pospíśil, Joanna Baum a Nandi Chinni Kumar. Ivo Pospísil (Brno) vystoupil s tématem Secular, Sacral, and Three Stages of Postsecular/Postpostsecular in Russian Literature - the Past and the Present, Joanna Baum (Gdaňsk) demonstrovala téma pesimismu a realismu (Pessimism or Realism. Alexander Kondratyev's Mythological Prose as a Personal View on Religion and Confession), Nandi Chinni Kumar (Haidarabád) přednesl referát na téma Post War and Post Secular Thought: The Experience of Faith and Identity in the Ida - Polish
Film. V modulu 5 (Polish Language Section) se zúčastnily Anna Gawarecka, Grażyna Gyłybow, Danuta Sosnowska aj. za předsednictví Iva Pospísila. Anna Gawarecka (Poznaň) se zabývala postsekulárními jevy v referátu Zdziwienie czy aprobata? Obraz doświadczenia religijnego w powieści Františki Jirousovej „Vyhnanci”. Magdalena Lubańska (Varšava) ukázala a vlastním filmem prezentovala téma Postpamieć o cierpieniu „homo sacer" na Podkarpaciu. Postsekularne rozważania antropologiczne, Danuta Sosnowska (Varšava) uvedla téma postsekularismu do zkoumání české literatury (Postsekularyzm jako propozycja badania czeskiej literatury po roku 1989 - w poszukiwaniu nowych jezyków dla wyrażenia doświadczenia wiary). Grażyna Szwat-Gyłybow (Varšava, PAN) vystoupila s tématem folkloru a spojila je se současným myšlením a pseudovědou jako novou vírou.

Účastníci konference byli požádáni, aby organizátorům poslali své kritické komentáře $\mathrm{k}$ jednotlivým př́spěvkům a $\mathrm{k}$ celé problematice. Napsal jsem asi deset stran textu, které teorii postsekularismus vztáhly $\mathrm{k}$ literatuře 20. století, zejména k české. Doufejme, že se brzy objeví publikace, která celou konferenci a všechny komentáře podnětně shrne.

prof. PhDr. Ivo Pospíšil, DrSc.

Ústav slavistiky

Filozofická fakulta, Masarykova univerzita

Arna Nováka 1, 60200 Brno, Česká republika

ivo.pospisil@phil.muni.cz 